\title{
Activation of matrix metalloproteinase- 9 by TNF- $\alpha$ in human urinary bladder cancer HT1376 cells: The role of MAP kinase signaling pathways
}

\author{
SE-JUNG LEE ${ }^{1}$, SUNG-SOO PARK ${ }^{2}$, YOUNG-HWA CHO ${ }^{2}$, KEERANG PARK ${ }^{2}$, EUN-JUNG KIM ${ }^{3}$, \\ KYUNG-HWAN JUNG ${ }^{1}$, SI-KWAN KIM ${ }^{4}$, WUN-JAE KIM ${ }^{3}$ and SUNG-KWON MOON ${ }^{1}$ \\ ${ }^{1}$ Department of Food and Biotechnology, Chungju National University, Chungju, Chungbuk 380-702; \\ ${ }^{2}$ Department of Biotechnology, Juseong College, Chungbuk 363-794; ${ }^{3}$ Department of Urology, Chungbuk \\ National University College of Medicine, Cheongju, Chungbuk 361-763; ${ }^{4}$ Department of Life Science, \\ College of Biomedical and Health Science, Konkuk University, Chungju, Chungbuk 380-701, Korea
}

Received August 13, 2007; Accepted October 1, 2007

\begin{abstract}
The expression of matrix metalloproteinase-9 (MMP-9) has been implicated in tumor invasion and metastasis. In this study, the factors and signaling pathways that are involved in the regulation of the MMP-9 expression were examined in urinary bladder cancer HT1376 cells. Tumor necrosis factor- $\alpha$ (TNF- $\alpha$ ) stimulated the secretion of MMP-9 in HT1376 cells, as shown by zymography and immunoblot analysis. At the level of transcription, TNF- $\alpha$ also stimulated 5'-flanking promoter activity of MMP-9. Transcription factor $\mathrm{NF}-\kappa \mathrm{B}, \mathrm{AP}-1$ and $\mathrm{Sp}-1$ binding sites were identified by a gel shift assay to be cis-elements for TNF- $\alpha$ activation of the MMP-9 promoter. TNF- $\alpha$ activates multiple signaling pathways in HT1376 cells, including the extracellular signalregulated kinase (ERK1/2), p38 MAP kinase and JNK pathways. Chemical inhibitors, which specifically inhibit each of these TNF- $\alpha$-activated pathways, were used to examine the signaling pathways involved in TNF- $\alpha$-mediated MMP-9 expression. The ERK1/2 inhibitor, U0126 and the p38 MAP kinase inhibitor, SB203580, significantly downregulated TNF- $\alpha$-induced MMP-9 expression and promoter activity. The transactivation of TNF- $\alpha$-stimulated NF- $\kappa B$, AP-1 and Sp-1 were inhibited by U0126 and SB203580 treatment. In conclusion, the findings of the present study indicate that TNF- $\alpha$ induces MMP-9 expression in HT1376
\end{abstract}

Correspondence to: Dr Sung-Kwon Moon, Department of Food and Biotechnology, Chungju National University, 123 Geomdan-ri Iryu-myeon, Chungju, Chungbuk 380-702, Korea

E-mail: sumoon66@dreamwiz.com

Key words: human urinary bladder cancer HT1376 cells, matrix metalloproteinase- 9 , tumor necrosis factor- $\alpha$, NF-кB, AP-1, Sp-1, extracellular signal-regulated kinase 1/2, p38 MAP kinase cells by activating transcription factors, which are involved in the ERK1/2- and p38 MAP kinase-mediated control of MMP-9 regulation, namely, NF- $\mathrm{B}, \mathrm{AP}-1$ and $\mathrm{Sp}-1$.

\section{Introduction}

The early stages of bladder cancer are characterized by a dysplastic and proliferative urothelium that initially grows into the lumen of the bladder (1). Bladder tumors can be divided into two broad categories-superficial and invasive-based on growth patterns and biological behavior $(2,3)$. The majority of bladder cancers $(90 \%)$ are transitional cell carcinomas (TCC), which result from neoplastic lesions with environmental and occupational causal factors (4).

Matrix metalloproteinase (MMP) concentrations are elevated in many types of human cancers, such as breast, lung, gastric, ovarian, brain and bladder (5-8). Tumor growth and metastasis depend on the balance between the expression of genes that regulate angiogenesis and those that control invasion $(9,10)$. The process of invasion is regulated by MMP expression, as MMP activity is responsible for the degradation of the extracellular matrix and basal membranes $(11,12)$. MMP-2 (gelatinase A, 72 kDa gelatinase) and MMP-9 (gelatinase B, $92 \mathrm{kDa}$ gelatinase) are of particular importance in this step since they hydrolyze type IV collagen in the basal membrane. Expression of MMP-2 and MMP-9 are higher in invasive compared with superficial bladder tumors (13). MMP-9 expression was correlated with high grade and stage of the tumors (14). Expression of MMPs, especially of MMP-9, in tissue, serum and urine of patients with TCC correlated with disease progression and metastasis $(1,13,15,16)$.

Tumor necrosis factor- $\alpha(\mathrm{TNF}-\alpha)$, a proinflammatory cytokine, which is sometimes also regarded as a growth factor, plays a major role in a wide variety of tumors $(17,29,30)$. Previously, it was suggested that TNF- $\alpha$ may contribute to the progression of urinary bladder cancer (18). TNF- $\alpha$ induces MMP-9 expression in a variety of cell types (19-23,31). In addition, recent results have demonstrated that TNF- $\alpha$-induced 
MMP-9 expression is mediated by increased activities of $\mathrm{NF}-\kappa \mathrm{B}$ and AP-1 and involves the activation of the MAP kinase pathway in several cell lines $(17,23-28,35)$. Although a recent study demonstrated that TNF- $\alpha$ induced MMP-9 expression in urinary bladder cancer cells (31), the factors and signaling pathways involved in MMP-9 expression in urinary bladder cancer cells are yet to be identified. In the present study, the role and importance of the signaling pathway in the transcriptional regulation of MMP-9 in TNF- $\alpha$-treated HT1376 cells was examined.

\section{Materials and methods}

Materials. TNF- $\alpha$ was obtained from R\&D systems (Minneapolis, MN). U0126, SP600125, U0126 and SB203580 were purchased from Calbiochem (San Diego, CA). Polyclonal antibodies to ERK1/2, phosphor-ERK1/2, p38 MAP kinase, phosphor-p38 MAP kinase, JNK and phosphorJNK were obtained from Cell signaling (Danvers, MA). The polyclonal MMP-9 antibody was obtained from Chemicon Transduction Laboratories (Temecula, CA).

Cell culture. The human bladder carcinoma cell line, HT1376, was obtained from the American Type Culture Collection. The cells were maintained in DMEM (4.5 g glucose/liter) supplemented with $10 \%$ fetal calf serum, L-glutamine and antibiotics (Biological Industries, Beit Haemek, Israel) at $37^{\circ} \mathrm{C}$ in a $5 \% \mathrm{CO}_{2}$ humidified incubator.

Zymography. Conditioned medium and cell lysates were electrophoresed in a polyacrylamide gel containing $1 \mathrm{mg} / \mathrm{ml}$ gelatin. The gel was then washed once at room temperature for $2 \mathrm{~h}$ with $2.5 \%$ Triton $\mathrm{X}-100$ and subsequently at $37^{\circ} \mathrm{C}$ overnight in a buffer containing $10 \mathrm{mM} \mathrm{CaCl}_{2}, 150 \mathrm{mM} \mathrm{NaCl}$, and $50 \mathrm{mM}$ Tris- $\mathrm{HCl}, \mathrm{pH}$ 7.5. The gel was stained with $0.2 \%$ Coomassie blue and photographed on a light box. Proteolysis was detected as a white zone in a dark blue field.

Immunoblot analysis. Growth-arrested cells were treated with TNF- $\alpha$ for specified time periods at $37^{\circ} \mathrm{C}$. Cell lysates were prepared and immunoblotting was performed as described previously (23).

Creation of MMP-9 promoter reporter construct and transient transfection. A 710 bp segment (pGL2-MMP-9WT) at the 5 '-flanking region of the human MMP-9 gene was amplified by PCR using specific primers from the human MMP-9 gene (Accession No. D10051): 5'-ACATTTGCCCGAGCTCCTG AAG (forward/SacI) and 5'-AGGGGCTGCCAGAAGCTTA TGGT (reverse/HindIII) (23).

The plasmid was transfected into HT1376 cells using a luciferase assay system (Promega, Madison, WI) according to the manufacturer's instructions (23). Firefly luciferase activities were standardized for $\beta$-galactosidase activity.

Nuclear extracts and electrophoretic mobility shift assay (EMSA). Nuclear extracts were prepared essentially as described elsewhere (23). An electrophoretic mobility shift assay was performed as described previously (23). The sequences were as follows: $\mathrm{NF}-\kappa \mathrm{B}, \mathrm{CAGTGGAATTCCC}$
CAGCC; AP-1, CTGACCCCTGAGTCAGCACTT; and, Sp-1, GCCC ATTCCTTCCGCCCCCAGATGAAGCAG.

Statistical analysis. When appropriate, data were expressed as means \pm SE. Data were analyzed by factorial ANOVA and Fisher's least significant difference test when appropriate. Statistical significance was set at $\mathrm{P}<0.05$.

\section{Results}

Effect of TNF- $\alpha$ on MMP expression in HT1376 cells. HT1376 cells were treated with various concentrations of TNF- $\alpha$. Without TNF- $\alpha$, the conditioned media from the HT1376 cells showed very low MMP-9 gelatinolytic activity (Fig. 1A). TNF- $\alpha$ induced a dose-dependent increase in MMP-9 activity (Fig. 1A). The increase in MMP-9 activity was detectable within $6 \mathrm{~h}$ after TNF- $\alpha$ treatment and remained elevated for up to $24 \mathrm{~h}$ after the addition of TNF- $\alpha$ (Fig. 1B). Similar results were found in cell lysates and immunoblot analysis (Fig. 1A, $\mathrm{B}, \mathrm{C}$ and D). However, under similar experimental conditions, the expression of another matrix metalloproteinase, MMP-2, remained essentially unchanged.

TNF- $\alpha$ activates the human MMP-9 gene promoter through $N F-\kappa B, A P-1$ and $S p-1$. The 5'-regulatory region of the human MMP-9 gene has been documented $(19,20,32)$. Therefore, a plasmid containing a luciferase reporter gene driven by a $710 \mathrm{bp}$ segment from the 5'-promoter region of the MMP-9 gene was used to examine TNF- $\alpha$-mediated MMP-9 promoter activation in HT1376 cells. HT1376 cells were transiently transfected with a plasmid pGL2-MMP-9WT and subsequently treated with TNF- $\alpha$ for $24 \mathrm{~h}$. The results showed that TNF- $\alpha$ activated the $-710 \mathrm{bp}$ promoter (Fig. 2B). A promoter fragment in the -710 and $-29 \mathrm{bp}$ region contained several consensus motifs for the NF-кB, AP-1 and Sp-1 transcription factors $(17,19,20,32)$. In order to determine if TNF- $\alpha$-induced MMP-9 expression was associated with an increase in the quantity of $\mathrm{NF}-\kappa \mathrm{B}, \mathrm{AP}-1$ and $\mathrm{Sp}-1$ in the nucleus, an electrophoretic mobility shift assay (EMSA) was performed using nuclear extracts of HT1376 cells treated with TNF- $\alpha(100 \mathrm{ng} / \mathrm{ml})$. An oligonucleotide derived from the MMP-9 promoter sequence spanning this motif bound specifically to nuclear factors derived from TNF- $\alpha$-stimulated HT1376 cells (Fig. 2C). Nuclear extracts from HT1376 cells treated with TNF- $\alpha$ showed an increased binding to the NF- $\mathrm{kB}$, AP-1 and Sp-1 motifs (Fig. 2C).

Effects of TNF- $\alpha$ on ERK1/2, JNK and p38 MAP kinase activation in HT1376 cells. To clarify whether TNF- $\alpha$ affects MAP kinase activation, time course experiments, measuring ERK1/2, JNK and p38 MAP kinase activation in response to TNF- $\alpha$, were performed in HT1376 cells. The results of these experiments indicated that ERK1/2, JNK and p38 MAP kinase were significantly activated by TNF- $\alpha$ (Fig. 3A). The effects of specific kinase inhibitors on the activation of MAP kinase were then analyzed. U0126 is known to selectively block the activity of MAP kinase (MEK), which activates ERK1/2 kinases. SB203580 is a specific inhibitor of p38 MAP kinase and SP600125 inhibits JNK activity. TNF- $\alpha$-induced phosphorylation of the MAP kinases (ERK1/2, p38 MAPK 
A

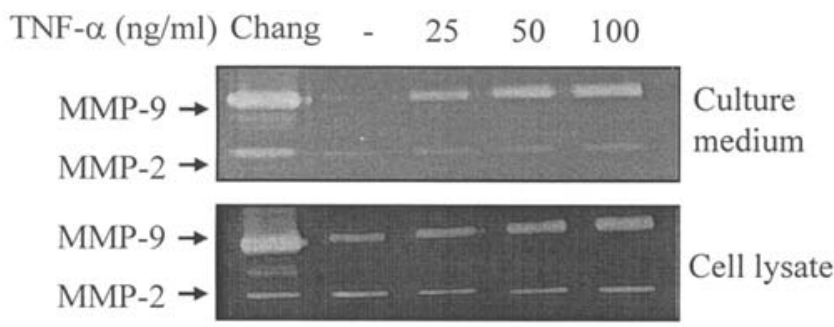

C

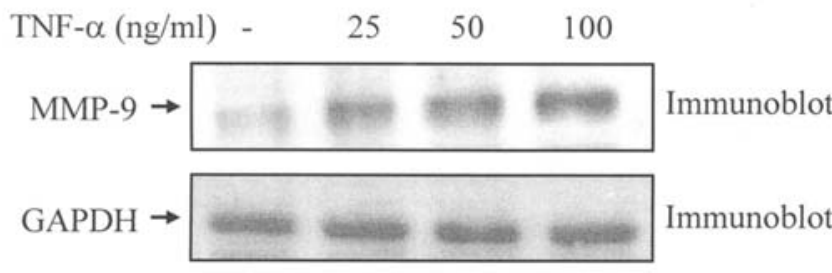

B

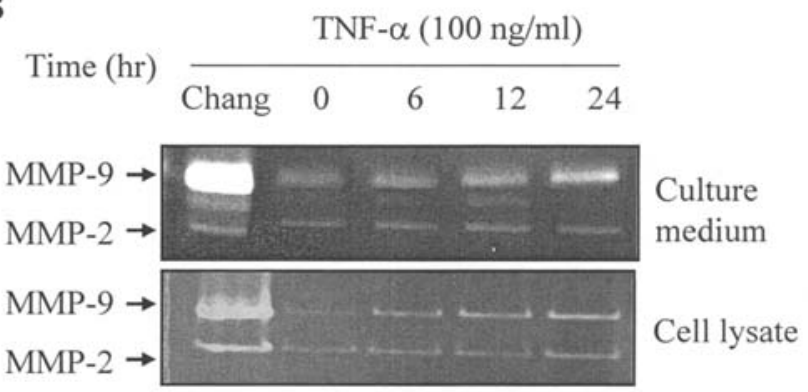

D Time (hr) $\frac{\text { TNF- } \alpha(100 \mathrm{ng} / \mathrm{ml})}{0 \quad 6 \quad 12 \quad 24}$

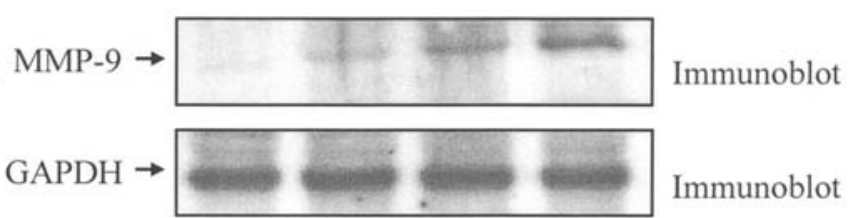

Figure 1. Gelatinolytic activity and MMP-9 expression of HT1376 cells treated with TNF- $\alpha$. Conditioned media and cell lysates were analyzed zymographically for MMP activities (A). Similarly, an immunoblot analysis (C) was performed with an antibody specific for MMP-9. Panels B and D show the time course of TNF- $\alpha$ treatment on MMP-9 gelatinolytic activity and MMP-9 expression. A medium conditioned by human hepatocyte Chang cells, expressing both MMP-2 and MMP-9, was used as a positive control.

A

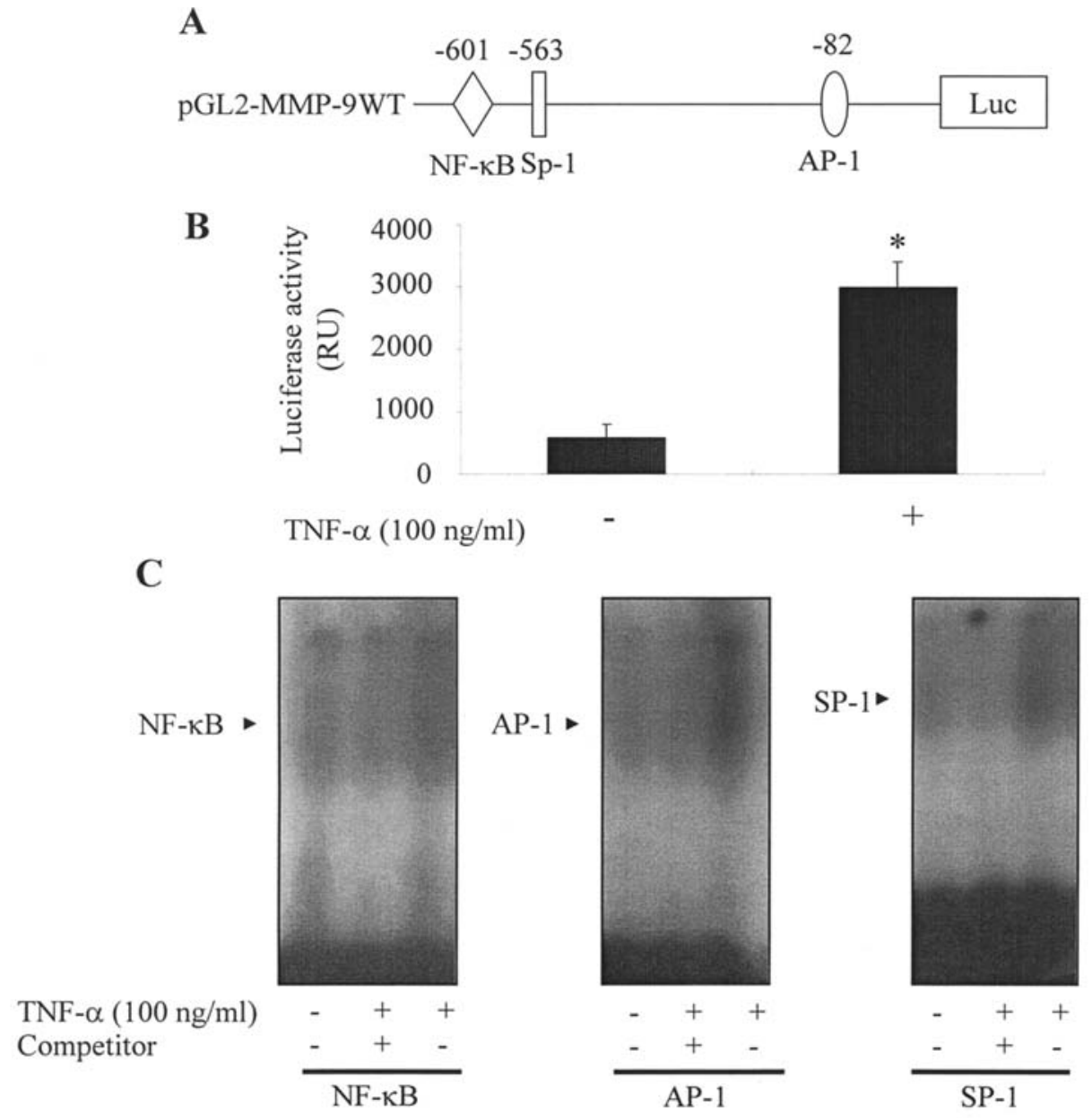

Figure 2. MMP-9 promoter activity and DNA binding activities of NF- $\mathrm{B}$, AP-1 and Sp-1 motifs derived from the MMP-9 promoter in TNF- $\alpha$-treated HT1376 cells. (A) Schematic map of the MMP-9 promoter showing the cis-regulatory elements. (B) Cells were transiently transfected with pGL2-MMP-9WT and were then cultured with TNF- $\alpha(100 \mathrm{ng} / \mathrm{ml})$. Luciferase activity was determined in the cell lysates as described in 'Materials and methods'. Results are presented as means \pm SE for three triplicate experiments. $\mathrm{P}<0.05$ compared with no TNF- $\alpha$ treatment. (C) Nuclear extracts from the cells were analyzed by EMSA for the activated NF- $\mathrm{KB}, \mathrm{AP}-1$ and $\mathrm{Sp}-1$ using radiolabeled oligonucleotide probes. 


\section{A}

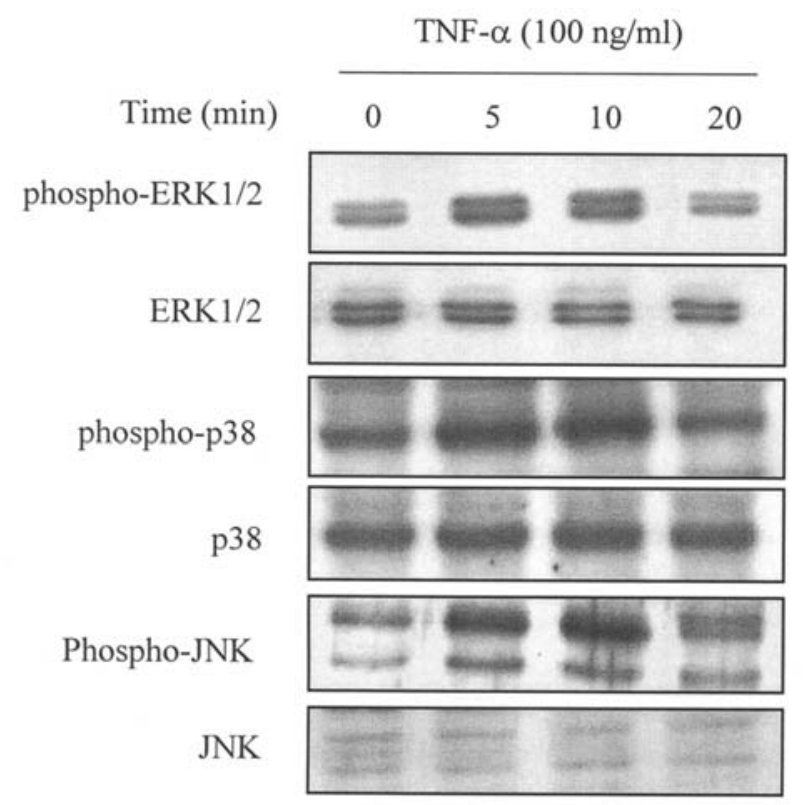

\section{B}

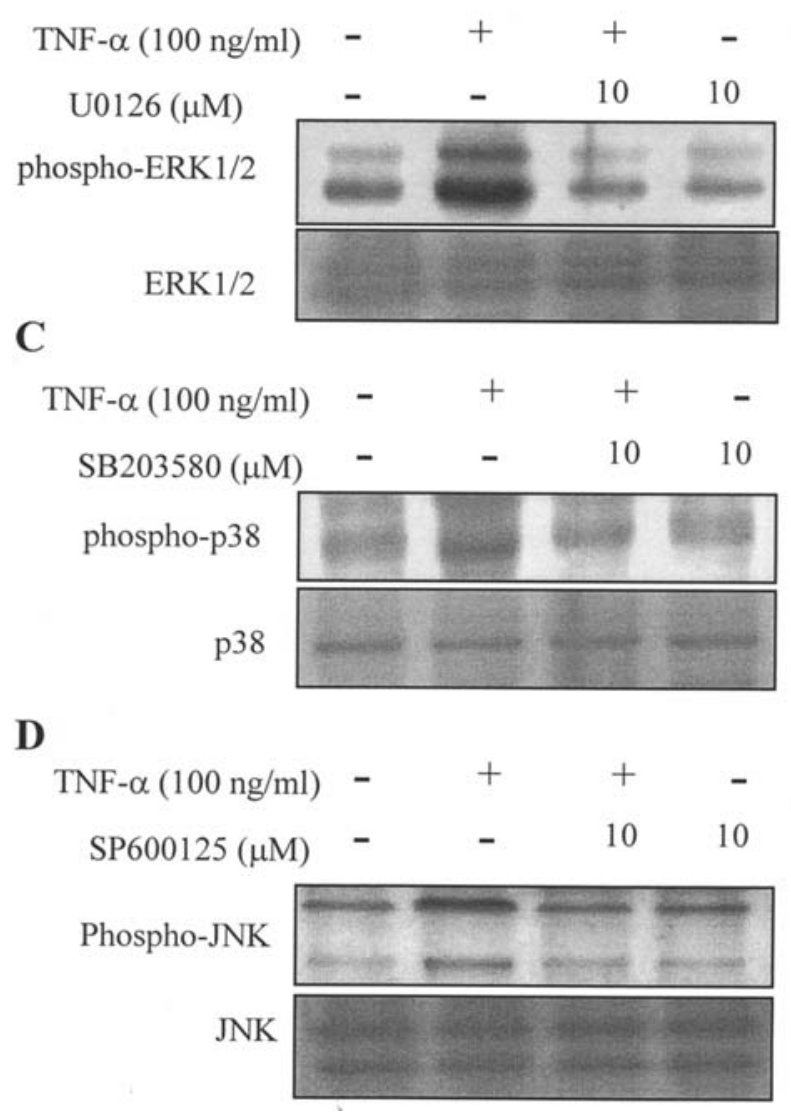

Figure 3. TNF- $\alpha$ induced ERK1/2, JNK and p38 MAP kinase phosphorylation. (A) Cells were harvested, lysed and the phosphorylation levels of ERK1/2, JNK and p38 MAP kinase were detected by immunoblot analysis using antibodies phospho-specific for ERK1/2, JNK and p38 MAP kinase. (B) HT1376 cells were pretreated for $40 \mathrm{~min}$ with $10 \mu \mathrm{M}$ of U0126, SB203580 and SP600125 before cells were treated with TNF- $\alpha$ (100 ng/ml) after $10 \mathrm{~min}$.

and JNK) was inhibited by U0126, SB203580 and SP600125 (Fig. 3B, C and D). These results suggest that TNF- $\alpha$ induced the activation of ERK1/2, p38 MAP kinase and JNK in HT1376 cells.

Effects of MAP kinase activities on MMP-9 expression. The subsequent experiments were designed to elucidate the signaling cascades that turn on the expression of the MMP-9 gene in HT1376 cells in response to TNF- $\alpha$. Prior to stimulation with TNF- $\alpha$, the cells were incubated with U0126, SB203580 and SP600125, respectively. U0126 and SB203580 caused a significant decrease in TNF- $\alpha$-induced MMP-9 expression in the culture medium and cell lysates at $10 \mu \mathrm{M}$ concentrations (Fig. 4A). However, SP600125 had no effect on TNF- $\alpha$-induced MMP-9 activity (Fig. 4A). These results suggest that ERK1/2 and p38 MAP kinase activity contributed to the up-regulation of MMP-9 expression in HT1376 cells in response to TNF- $\alpha$. Since the ERK and p38 MAP kinase pathways play a major role in TNF- $\alpha$-mediated expression of MMP-9, the possibility that U0126 and SB203580 inhibited TNF- $\alpha$-mediated MMP-9 activity due to decreased transcription was examined. HT1376 cells were transiently transfected with a plasmid pGL2-MMP-9WT and subsequently treated with TNF- $\alpha$ in the absence or presence of U0126 and SB203580. U0126 and SB203580 inhibited TNF- $\alpha$-induced up-regulation of MMP-9 transcription and had no effect on basal activity of the MMP-9 promoter (Fig. 4B).
These data suggested that ERK1/2 and p38 MAP kinase may contribute to TNF- $\alpha$-mediated up-regulation of MMP-9 promoter activity at the level of transcription.

U0126 and SB203580 decrease TNF- $\alpha$-mediated DNA binding activity of $N F-\kappa B, A P-1$ and $S p-1$. The results from the present study show that TNF- $\alpha$ regulated MMP-9 expression through the NF-кB, AP-1 and Sp-1 motifs in the MMP-9 promoter (Fig. 2C). Moreover, TNF- $\alpha$-mediated MMP-9 activity was inhibited by U0126 and SB203580 (Fig. 4A and B.) Thus, it is likely that the inhibitory effects of U0126 and SB203580 on MMP-9 expression are mediated, at least in part, through these motifs. In order to address this hypothesis, gel shift assays were performed as described above (see Materials and methods). U0126 and SB203580 effectively inhibited the increase in NF-кB, AP-1 and Sp-1 binding activities (Fig. 4C). These results suggested that NF- $\mathrm{BB}, \mathrm{AP}-1$ and $\mathrm{Sp}-1$ were involved in ERK1/2- and p38 MAP kinase-mediated control of the MMP-9 gene in HT1376 cells.

\section{Discussion}

Previous studies have shown that MMPs, specifically MMP-2 and MMP-9, are associated with a high stage and grade of bladder cancer $(13,14)$. It has also been reported that MMP-9, though not MMP-2, was detected in bladder washes (1) and that the expression of MMP-9 correlated with a higher stage 
A

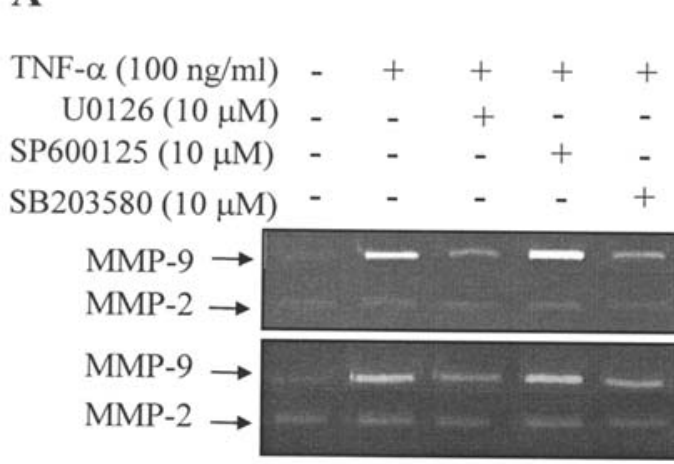

C

\begin{tabular}{lllll} 
& \multicolumn{4}{c}{ NF-kB } \\
\cline { 2 - 5 } Competitor & - & - & - & - \\
TNF- $\alpha(100 \mathrm{ng} / \mathrm{ml})$ & - & + & + & + \\
$\mathrm{U} 0126(10 \mu \mathrm{M})$ & - & - & + & - \\
$\mathrm{SB} 203580(10 \mu \mathrm{M})$ & - & - & - & +
\end{tabular}

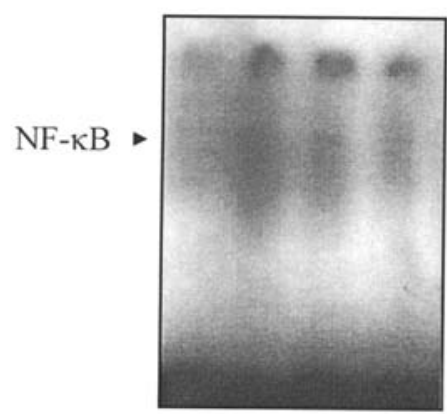

B

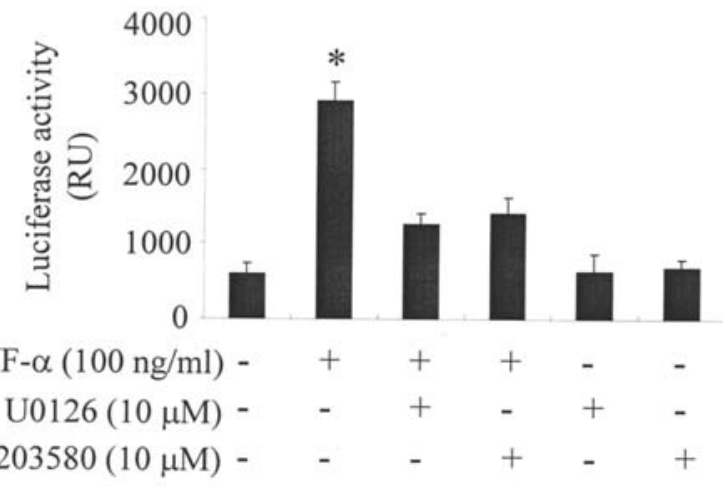
SB203580 $(10 \mu \mathrm{M})$ -

Culture medium

Cell lysate

\begin{tabular}{cccc}
\multicolumn{3}{c}{ Sp-1 } \\
\hline- & - & - & - \\
- & + & + & + \\
- & - & + & - \\
- & - & - & +
\end{tabular}

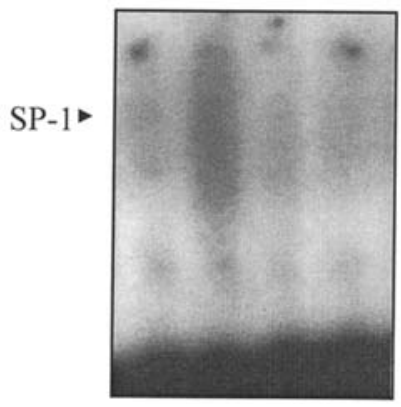

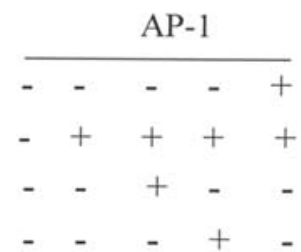

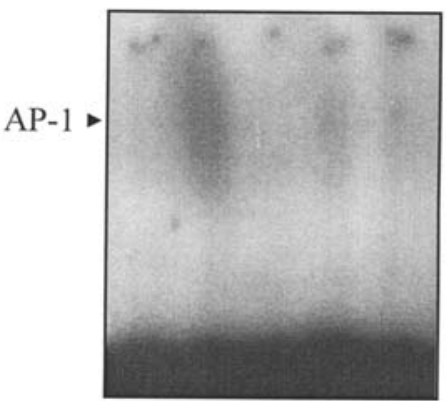

Figure 4. Effects of U0126, SB203580 and SP600125 on MMP-9 production, promoter activity and DNA binding activities of NF-кB, AP-1 and Sp-1 motifs derived from the MMP-9 promoter in TNF- $\alpha$-treated HT1376 cells. (A) Growth-arrested cells were stimulated with TNF- $\alpha$ (100 ng/ml) in the presence or absence of several inhibitors and then the culture medium, cell lysates and zymographic assays were analyzed for MMP-9 production. (B) MMP-9 promoter activity in TNF- $\alpha$-induced HT1376 cells in the presence of U0126, SB203580 and SP600125. Results are presented as means \pm SE for three triplicate experiments. P<0.05 compared with no TNF- $\alpha$ treatment in pGL2-MMP-9WT transfected HT1376 cells. (C) Growth-arrested cells were stimulated with TNF- $\alpha$ (100 ng/ml) in the presence or absence of U0126 and SB203580. Nuclear extracts from the cells were analyzed by EMSA for activated NF-кB, AP-1 and Sp-1 using radiolabeled oligonucleotide probes.

and grade of the bladder tumors (14). Relative MMP-9 activity was increased 17 -fold in patients with invasive tumors compared with healthy volunteers, indicating the probable importance of this enzyme in bladder cancer (14). However, the molecular mechanisms involved in the expression of MMP-9 in urinary bladder cancer cells are poorly understood.

As outlined previously, MMP-9 may play a role in basement membrane disruption, a process which is necessary for further invasion and metastasis (9-12). Inflammatory cytokines, particularly TNF- $\alpha$ induce MMP-9 production in normal human fibroblasts (33), fibrosarcoma cells (34) and vascular smooth muscle cell lines (23). In the first stage of this investigation, TNF- $\alpha$-mediated MMP-9 induction was confirmed in HT1376 cells by zymography and determination of protein and promoter activity levels. However, MMP-2 activity remained essentially unchanged. These data suggest that HT1376 cells express MMP-9 upon stimulation with TNF- $\alpha$, consistent with a previous report indicating that TNF- $\alpha$ express MMP-9 production in bladder cancer cells (31).

Previous studies analyzing the MMP-9 promoter identified an essential proximal AP-1 element and upstream Sp-1 and $\mathrm{NF}-\kappa \mathrm{B}$ sites in tumor cell lines in response to TNF- $\alpha(19,28)$.
Recent studies show that the transcription factors, NF- $\mathrm{kB}$ and Ap-1, are involved in the regulation of TNF- $\alpha$-mediated MMP-9 expression in different cell lines $(19,21,23)$. However, the identification and role of cis-elements in the TNF- $\alpha$ mediated induction of MMP-9 in bladder cancer cells have not been addressed to date. The results from the luciferase assays in the HT1376 cells indicated that the MMP-9 promoter region, spanning -710 to $-29 \mathrm{bp}$, which contains the NF-кB, Sp-1 and AP-1 binding sites, is required for stimulation by TNF- $\alpha$. The gel-shift assay confirmed induction of NF-кB, AP-1 and Sp-1 DNA-binding activity by TNF- $\alpha$ in HT1376 cells. The present study is the first to systemically investigate, using the promoter and gel-shift assays, the existence of three potential TNF- $\alpha$-binding sites, NF-кB, AP-1 and Sp-1, within the -710 bp 5'-flanking sequence of the human MMP-9 gene in bladder cancer cells. It was concluded that the NF- $\mathrm{BB}, \mathrm{AP}-1$ and Sp-1 sites are important for TNF- $\alpha$ mediated activation of MMP-9 gene transcription in HT1376 cells.

Several studies have identified signal transduction pathways that are involved in the regulation of MMP-9 expression in tumor cell lines (26-28,35), endothelial cells (17), keratinocytes (24) and vascular smooth muscle cells (23). 
However, in bladder cancer cells, the issue of how the activation of signaling pathways results in the induction of MMP-9 is unclear. The present study identified potential cisacting elements of the signal pathway-mediated control of the MMP-9 gene in HT1376 cells in response to TNF- $\alpha$. The data show that ERK1/2 and p38 MAP kinase are major factors in the regulation of TNF- $\alpha$-induced MMP-9 expression in HT1376 cells. The inhibition of JNK phosphorylation by preincubation with SP600125 had no effect on TNF- $\alpha$-induced MMP-9 expression in HT1376 cells. A notable finding in this study was that the induction of MMP-9 by TNF- $\alpha$ was not dependent on the activation of a single pathway, though rather was dependent on at least the ERK and p38 MAP kinase pathways. Although multiple signaling pathways were previously shown to be involved in MMP-9 expression in different cell types $(26,35)$, the present study is the first to report that TNF- $\alpha$ up-regulates MMP-9 via the simultaneous activation of different pathways in bladder cancer cells. This finding has broadened our understanding of the regulation of this important molecule, which is involved in urinary bladder tumor invasion and metastasis.

The transcription factors, $\mathrm{NF}-\kappa \mathrm{B}, \mathrm{AP}-1$ and $\mathrm{Sp}-1$, were the focus of this investigation into how ERK1/2 and p38 MAP kinase mediate MMP-9 expression, as they are necessary for MMP-9 secretion (Fig. 2B and C). The transcription factors that are involved in ERK- and p38 MAP kinase-mediated control of the MMP-9 gene in HT1376 cells in the presence of TNF- $\alpha$ were identified. The results of the present study clearly show that the ability of U0126 and SB203580 to reduce MMP-9 expression in HT1376 cells is achieved via reductions in NF-кB, AP-1 and Sp-1 binding (Fig. 4C), thus suggesting that $\mathrm{NF}-\kappa \mathrm{B}, \mathrm{AP}-1$ and $\mathrm{Sp}-1$ activities may play a role in the ERK1/2- and p38 MAP kinase-mediated regulation of MMP-9 in HT1376 cells. It is possible that, NF- $\mathrm{KB}, \mathrm{AP}-1$ and Sp-1, regulated by ERK1/2 and p38 MAP kinase, cooperate in activating the MMP-9 gene.

Collectively, the results of the present study are consistent with two main conclusions: i) TNF- $\alpha$ regulates MMP-9

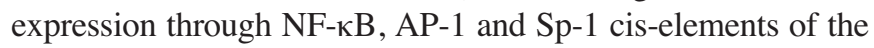
gene promoter; and ii) ERK1/2 and p38 MAP kinase mediate TNF- $\alpha$-induced MMP- 9 expression by coordinating the regulation of the binding activity of the transcription factors, NF- $\mathrm{B}, \mathrm{AP}-1$ and Sp-1, in HT1376 cells.

\section{Acknowledgements}

This study was supported by the Regional Industrial Technology Development Program of the Ministry of Commerce, Industry and Energy in Korea (Grant No. 10018327) and Korea Industrial Technology Foundation through the Human Resource Training Project for Regional Innovation.

\section{References}

1. Bianco FJJ, Gervasi DC, Tiguert R, Grignon DJ, Pontes JE, Crissman JD, Fridman R and Wood DP Jr: Matrix metalloproteinase-9 expression in bladder washes from bladder cancer patients predicts pathological stage and grade. Clin Cancer Res 4: 3011-3016, 1998.

2. Prout GR, Griffin PP and Shipley WU: Bladder carcinoma as systemic disease. Cancer 43: 2532-2539, 1979.
3. Herman P and Sobin LH: TNM Classification of Malignant Tumours (eds). 4th edition Springer-Verlag, Berlin, pp197, 1987.

4. Raghavan D: Molecular targeting and pharmacogenomics in the management of advanced bladder cancer. Cancer 97: 2083-2089, 2003.

5. Kleiner DE and Stetler-Stevenson WG: Matrix metalloproteinases and metastasis. Cancer Chemother Pharmacol 43: S42-S51, 1999.

6. Zucker S, Lysik RM, DiMassimo BI, Zarrabi HM, Moll UM, Grimson G, Tickle SP and Docherty AJ: Plasma assay of gelatinase B: tissue inhibitor of metalloproteinase complexes in cancer. Cancer 76: 700-708, 1995.

7. Naylor MS, Stamp GW, Davies BD and Balkwill FR: Expression and activity of MMPS and their regulators in ovarian cancer. Int $\mathbf{J}$ Cancer 58: 50-56, 1994.

8. Forsyth PA, Wong H, Laing TD, Rewcastle NB, Morris DG, Muzik H, Leco KJ, Johnston RN, Brasher PM, Sutherland G and Edwards DR: Gelatinase-A (MMP-2), gelatinase-B (MMP-9) and membrane type matrix metalloproteinase-1 (MT1-MMP) are involved in different aspects of the pathophysiology of malignant gliomas. Br J Cancer 79: 1828-1835, 1999.

9. Fidler IJ, Kumar R, Bielenberg DR and Ellis LM: Molecular determinants of angiogenesis in cancer metastasis. Cancer J Sci Am 4: S58-S66, 1998.

10. Kumar R and Fidler IJ: Angiogenic molecules and cancer metastasis. In Vivo 1: 27-34, 1998.

11. Liotta LA: Tumor invasion and metastasis - role of extracellular matrix: Rhoads Memorial Award Lecture. Cancer Res 46: 1-7, 1986.

12. Welgus HG, Campbell EJ, Cury JD, Eisen AZ, Senior RM, Wilhelm SM and Goldberg GI: Neutral metalloproteinases produced by human mononuclear phagocytes: enzyme profile, regulation and expression during cellular development. J Clin Invest 86: 1496-1502, 1990.

13. Davies B, Waxman J, Wasan H, Abel P, Williams G, Krausz T, Neal D, Thomas D, Hanby A and Balkwill F: Levels of matrix metalloproteases in bladder cancer correlate with tumor grade and invasion. Cancer Res 53: 5365-5369, 1993.

14. Nutt JE, Durkan GC, Mellon JK and Lunec J: Matrix metalloproteinases (MMPs) in bladder cancer: the induction of MMP9 by epidermal growth factor and its detection in urine. BJU Int 91: 99-104, 2003.

15. Ozdemir E, Kakehi Y, Okuno $\mathrm{H}$ and Yoshida O: Role of matrix metalloproteinase- 9 in the basement membrane destruction of superficial urothelial carcinoma. J Urol 161: 1359-1363, 1999.

16. Moses MA, Wiederschain D, Loughlin KR, Zurakowski D, Lamb CC and Freeman MR: Increased incidence of matrix metalloproteinases in urine of cancer patients. Cancer Res 58: 1395-1399, 1999.

17. Genersch E, Hayess K, Neuenfeld Y and Haller H: Sustained ERK phosphorylation is necessary but not sufficient for MMP-9 regulation in endothelial cells: involvement of Ras-dependent and -independent pathways. J Cell Sci 113: 4319-4330, 2003.

18. Raziuddin S, Masihuzzaman M, Shetty S and Ibrahim A: Tumor necrosis factor alpha production in schistosomiasis with carcinoma of urinary bladder. J Clin Immunol 13: 23-29, 1993.

19. Sato H and Seiki M: Regulatory mechanism of $92 \mathrm{kDa}$ type IV collagenase gene expression which is associated with invasiveness of tumor cells. Oncogene 8: 395-405, 1993.

20. Sato H, Kita M and Seiki M: v-Src activates the expression of 92-kDa type IV collagenase gene through the AP-1 site and the GT box homologous to retinoblastoma control elements: A mechanism regulating gene expression independent of that by inflammatory cytokines. J Biol Chem 268: 23460-23468, 1993.

21. Bond M, Rosalind P, Fabunmi P, Baker AH and Newby AC: Synergistic upregulation of metalloproteinase- 9 by growth factors and inflammatory cytokines: An absolute requirement for transcription factor NF-kappa B. FEBS Lett 435: 29-34, 1998

22. Farina AR, Tacconelli A, Vacca A, Maroder M, Gulino A and Mackay AR: Transcriptional up-regulation of matrix metalloproteinase-9 expression during spontaneous epithelial to neuroblast phenotype conversion by SK-N-SH neuroblastoma cells, involved in enhanced invasivity, depends upon GT-box and nuclear factor NF-kB elements. Cell Growth Differ 10: 353-367, 1999. 
23. Moon SK, Cha BY and Kim CH: ERK1/2 mediates TNF-alphainduced matrix metalloproteinase-9 expression in human vascular smooth muscle cells via the regulation of NF-kappaB and AP-1: Involvement of the ras dependent pathway. J Cell Physiol 198: 417-427, 2004.

24. Holvoet S, Vincent C, Schmitt D and Serres M: The inhibition of MAPK pathway is correlated with down-regulation of MMP-9 secretion induced by TNF-alpha in human keratinocytes. Exp Cell Res 290: 108-119, 2003.

25. Wiehler S, Cuvelier SL, Chakrabarti S and Patel KD: p38 MAP kinase regulates rapid matrix metalloproteinase-9 release from eosinophils. Biochem Biophys Res Commun 315: 463-470, 2004.

26. Cohen M, Meisser A, Haenggeli L and Bischof P: Involvement of MAPK pathway in TNF-alpha-induced MMP-9 expression in human trophoblastic cells. Mol Hum Reprod 12: 225-232, 2006.

27. Simon C, Goepfert $\mathrm{H}$ and Boyd D: Inhibition of the p38 mitogen-activated protein kinase by SB 203580 blocks PMAinduced $\mathrm{Mr}$ 92,000 type IV collagenase secretion and in vitro invasion. Cancer Res 58: 1135-1139, 1998.

28. Gum R, Lengyel E, Juarez J, Chen JH, Sato H, Seiki M and Boyd D: Stimulation of $92-\mathrm{kDa}$ gelatinase B promoter activity by ras is mitogen-activated protein kinase kinase 1 -independent and requires multiple transcription factor binding sites including closely spaced PEA3/ets and AP-1 sequences. J Biol Chem 271: 10672-10680, 1996.

29. Baud V and Karin M: Signal transduction by tumor necrosis factor and its relatives. Trends Cell Biol 11: 372-377, 2001.
30. Wajant H, Pfizenmaier K and Scheurich P: Tumor necrosis factor signaling. Cell Death Differ 10: 45-65, 2003.

31. Shin KY, Moon HS, Park HY, Lee TY, Woo YN, Kim HJ, Lee SJ and Kong G: Effects of tumor necrosis factor-alpha and interferon-gamma on expressions of matrix metalloproteinase-2 and -9 in human bladder cancer cells. Cancer Lett 159: 127-134, 2000.

32. Huhtala P, Chow L and Trygvason K: Structure of the human type IV collagenase gene. J Biol Chem 265: 11077-11082, 1990.

33. Unemori EN, Hibbs MS and Amento EP: Constitutive expression of a 92-kD gelatinase (type V collagenase) by rheumatoid synovial fibroblasts and its induction in normal human fibroblasts by inflammatory cytokines. J Clin Invest 88 : $1656-1662,1991$.

34. Okada Y, Tsuchiya H, Shimizu H, Tomita K, Nakanishi I, Sato H, Seiki M, Yamashita K and Hayakawa T: Induction and stimulation of 92-kDa gelatinase/type IV collagenase production in osteosarcoma and fibrosarcoma cell lines by tumor necrosis factor alpha. Biochem Biophys Res Commun 171: 610-617, 1990.

35. Yao J, Xiong S, Klos K, Nguyen N, Grijalva R, Li P and Yu D Multiple signaling pathways involved in activation of matrix metalloproteinase-9 (MMP-9) by heregulin-beta1 in human breast cancer cells. Oncogene 20: 8066-8074, 2001. 